\title{
Effect Of L-Cysteine On Blood Picture And Some Serum Parameters In Rats Exposed To 2 Gauss Electro-Magnetic Field
}

\author{
Mervat Abdel-Rahman \\ Clinical pathology laboratory, Student hospital, Cairo University, Giza.
}

\begin{abstract}
Objective: investigation of the bio-effects of exposure to 2 gauss electromagnetic field (EMF) on blood elements, blood glucose, hepatocellular enzymes and bilirubin of mice and their possible modification by L-cysteine. Methods: the following groups were studied; (1) normal rats treated with saline; (2) normal rats treated with L-cysteine (18 mg/kg); (3) rats exposed to EMF for 21 days and treated with the vehicle (saline) during the exposure period; (4) rats exposed to EMF for 21 days and treated with L-cysteine (18 mg/kg orally, 3 times per week) during the exposure period; (5) rats exposed to EMF for 21 days and treated with the vehicle (saline) during the exposure period and for 45 days after exposure; (6) rats exposed to EMF for 21 days and treated with L-cysteine (18 $\mathrm{mg} / \mathrm{kg}$ orally, 3 times per week) during the exposure period and for 45 days after exposure; Results: in rats exposed to low frequency EMF for 21 days (group2), marked increase in aspartate aminotransferase (AST) and alanine aminotransferase (ALT) activities in serum was observed. Plasma bilirubin level was raised. Meanwhile, significant decrease in plasma glucose levels occured after exposure to EMF. No significant changes were observed in haemoglobin level, red blood cells or total leucocytic count noted in rats exposed to EMF. The elevations in serum bilirubin, AST and ALT levels were reduced to near normal values in rats given L-cysteine druing the 21 days of exposure (group3). On the other hand, in rats examined 45 days after the end of the exposure period (group 3), no significant alterations were noted as regards bilirubin, AST, ALT and glucose levels in serum. Conclusions: these results suggest that (1) exposure to low frequency EMF of $50 \mathrm{~Hz}$ is associated with some degree of liver injury reflected in increased leakage of hepatoceular enzymes into plasma as well as an increase in serum bilirubin; (2) these alterations can be ameliorated by the administration of L-cysteine, as well as; (3) by limiting exposure to EMF.
\end{abstract}

Key Words: Electro-magnetic field, liver enzymes, rat, blood picture

\section{Introduction}

In the recent years, there has been considerable research effort undertaken on the biological effects and potential hazards of low frequency electric and magnetic fields. Especialy in Egypt, where electric equipments are being used without earthing, there exists EMF of 1-3 gauss, because of the long extension of electric cables in work places, houses, laboratories, etc...

Studies suggested that EMF may influence the physiological processes in biological systems. In particular, the effects of low frequency EMF has received considerable interest (Pasquinelli et al., 1993; Petrini et al., 1990). It has been suggested that exposure to low frequency EMF of $75 \mathrm{~Hz}$ and an intensity of 20 Gauss caused an increase in mouse life span (Pasquinelli et al., 1993), while sub-acute exposure to EMF (128 $\mathrm{mT} 1$ hour/day for 10 consecutive days) stimulated plasma corticosterone and liver metallothionein activities in rats (Chater et al., 2004). In addition, epidemiological studies have implicated EMF exposure with 
increased risk of various types of cancer, including leukemia, brain and breast tumours (Wrensch et al., 1993; Savitz et al., 1988; Loomis et al., 1994).

One important mechanism, by which low frequency electro-magnetic field (EMF) may affect biological systems is the increasing generation of free radicals. Lalo et al (1994) and Kabuto et al (2001) suggested that steady MF could accelerate lipid peroxidation. It was also reported that $60 \mathrm{~Hz}$, MF increased the phorbol 12-myristate 13acetate (PMA) induced oxidative burst in neutrophils. Fiorani et al (1997) reported that MF $(50 \mathrm{~Hz}, 0.5 \mathrm{mT})$ increased the damage in an oxidative stressed rabbit erythrocyte system. Lee et al (2003), investigated whether ELF $(60 \mathrm{~Hz}) \mathrm{MF}$ can modulate antioxidant system in mouse brain by detecting chemilum-inescence and measuring superoxide dismutase (SOD) activity in homogenated organs. Their results suggest that $60 \mathrm{~Hz}, \mathrm{MF}$ could deteriorate antioxidant defensive system by reactive oxygen species (ROS), other than superoxide radicals.

Thiol compounds, such as glutathione (GSH), cysteine (CSH) and homocysteine (HCSH) are a natural reservoir of the reductive capacity of the cell. The most significant role played by thiols in vivo is their function as components of the intracellular and extracellular redox buffer. A diminished cellular GSH level accom-panies such pathological states as AIDS, liver cirrhosis, Crohn's disease and ulcerative colitis and also malnutrition (Reimund et al., 1998; Hadi Yasa et al., 1999; Choi et al., 2000). The pivotal role of redox cycle in maintaining the integrity of the biological system in the face of oxidative stress and other challenges is, therefore, of particular clinical relevance. In this respect, $\mathrm{N}$-acetyl-Lcysteine (NAC), an antioxidant and a GSH precursor, has been shown to ameliorate cytokine transcription and synthesis, in addition to suppressing ROS-mediated lung injury (Barrett et al., 1999; Haddad et al., 2001; Behrend et al., 2003).
The aim of this work is therefore to assess the potential impact of 2 gauss EMF on blood elements, blood glucose, liver and kidney functions of mice. In addition, the effect of the anti-oxidant L-cysteine was assessed.

\section{Materials and methods}

\section{Animals}

Male rats in the weight range of 100$120 \mathrm{~g}$ maintained on standard laboratory diet were used. Rats were randomized into 5 groups (6 rats/group). The following groups were studied; (1) normal rats treated with saline; (2) normal rats treated with L-cysteine $(18 \mathrm{mg} / \mathrm{kg})$; (3) rats exposed to EMF for 21 days and treated with the vehicle (saline) during the exposure period; (4) rats exposed to EMF for 21 days and treated with Lcysteine $(18 \mathrm{mg} / \mathrm{kg}$ orally, 3 times per week) during the exposure period; (5) rats exposed to EMF for 21 days and treated with the vehicle (saline) during the exposure period and for 45 days after exposure; (6) rats exposed to EMF for 21 days and treated with L-cysteine $(18 \mathrm{mg} / \mathrm{kg}$ orally, 3 times per week) during the exposure period and for 45 days therafter;

\section{Exposure facility}

Animals were exposed to a homogenous magnetic field generator in which animals can be housed and exposed as described earlier (Abdel Rahman, 2004). There was no measurable difference in temperature between the room and the chamber. The animals were kept in special plastic cages that permit normal ventilation and daylight. Food and water were allowed ad libitum and kept in special open containers fixed on the walls of the cages. The magnetic field exposure was locally manufactured (Cairo University).

\section{Biochemical assessment}

At the end of the experiments (21 days for group 1, 3 and 4 and 66 days for groups 2, 5 and 6), animals from different groups were 


\section{Mervat Abdel-Rahman}

anaesthetized with ether and blood samples were obtained from the retro-orbital vein plexsus. Laboratory investigations included complete blood picture, serum glucose, bilirubin, serum Aspartate aminotransferase (AST) and alanine aminotransferase (ALT) activities and bilirubin. Aspartate aminotransferase (AST) and alanine aminotransferase (ALT) activities in serum were measured colorimetrically (Crowley, 1967). Bilirubin in serum was determined as described by Bauer (1982).

\section{Statistical analysis}

All results are expressed as means $\pm \mathrm{SE}$. A two-tailed Student's $\mathrm{t}$ test was used. A probability value less than 0.05 was considered statistically significant (Loether \& Mc Tavish 1976).

\section{Results}

\section{Biochemical changes after exposure to EMF Early changes}

In rats exposed to low frequency EMF for 21 days, marked increase in aspartate aminotransferase (AST) and alanine aminotransferase (ALT) activities in serum was observed, indicating a form of hepatic injury. The serum AST and ALT levels were significantly elevated $(\mathrm{P}<0.01)$ from $92.4 \pm$ 2.2 and $42.6 \pm 2.6$ (saline control) to $148 \pm$ 5.5 and $84.6 \pm 3.4 \mathrm{IU} / \mathrm{L}$, respectively. This represented 60.2 and $98.6 \%$ increases over control values, respectively. Total bilirubin was also increased in plasma from control values of $0.19 \pm 0.29$ to $0.5 \pm 0.09 \mathrm{mg} \%$ $(\mathrm{P}<0.001)$. On the other hand, blood glucose was reduced by $35.6 \%(54.7 \pm 2.9 \mathrm{mg} \%)$. Control value was $84.8 \pm 4.6 \mathrm{mg} \%(\mathrm{P}<0.01)$. (Table 1).

In rats treated with L-cysteine during the time of exposure to EMF (21 days) and killed therafter, the elevations in AST, ALT and bilirubin were reduced to near normal values $(\mathrm{AST} ; 88.1 \pm 3$, ALT; $50.3 \pm 4.1$; bilirubin; $0.16 \pm 0.02$ ). The decrease in plasma glucose, on the other hand, was not improved by L-cysteine treatment (Table 1).

\section{Late changes}

Rats exposed to EMF for 21 days, but killed 45 days after the end of the exposure period showed no significant alterations in AST, ALT, bilirubin or glucose levels in serum, indicating that removal from the EMF can ameliorate the abnormalities seen during the exposure period. L-cysteine administration did not significantly change any of the parameters studied. However and unexpectedly, serum GPT was raised in those received L-cysteine for this long period (Table 1).

\section{Blood picture}

In rats exposed to EMF, no significant changes were observed as regards total leucocytic count, red blood cell count, haemoglobin level, haematocrite values, mean cell volume, or mean cell haemoglobin concentration.

Table 1. AST, ALT, bilirubin and glucose levels in serum of rats exposed to EMF (2 gauss) with or without L-cysteine treatment

\begin{tabular}{|c|c|c|c|c|c|c|}
\hline & $\begin{array}{c}\text { Normal } \\
\text { control }\end{array}$ & $\begin{array}{c}\text { Normal } \\
\text { controls + L- } \\
\text { Cysteine }\end{array}$ & $\begin{array}{c}\text { Exposed (2 } \\
\text { gauss) for 21 } \\
\text { days }\end{array}$ & $\begin{array}{c}\text { Exposed 21 } \\
\text { days + L- } \\
\text { Cysteine during } \\
\text { EMF exposure }\end{array}$ & $\begin{array}{c}\text { Exposed (2 gauss) } \\
\text { for 21 days and } \\
\text { killed 45 days after } \\
\text { the end of exposure } \\
\text { period }\end{array}$ & $\begin{array}{c}\text { Exposed (2 gauss) for 21 } \\
\text { days and killed 45 days after } \\
\text { the end of exposure period + } \\
\text { L-cysteine treatment since } \\
\text { beginning of EMF exposure }\end{array}$ \\
\hline AST & $92.4 \pm 2.2$ & $56.8 \pm 3.1$ & $148 \pm 5.5$ & $88.1 \pm 3$ & $70.6 \pm 4.0$ & $92.8 \pm 6.4$ \\
\hline ALT & $42.6 \pm 2.6$ & $47.8 \pm 4.2$ & $84.6 \pm 3.4$ & $50.3 \pm 4.1$ & $50.6 \pm 3.7$ & $80.8 \pm 6.9$ \\
\hline $\begin{array}{c}\text { Bilirubi } \\
\text { n }\end{array}$ & $0.19 \pm 0.29$ & $0.22 \pm 0.01$ & $0.5 \pm 0.09$ & $0.16 \pm 0.02$ & $0.18 \pm 0.02$ & $0.17 \pm 0.03$ \\
\hline Glucose & $84.8 \pm 4.6$ & $94 \pm 3.9$ & $54.7 \pm 2.9$ & $40.8 \pm 4.3$ & $96 \pm 6.2$ & $91.7 \pm 7.9$ \\
\hline
\end{tabular}




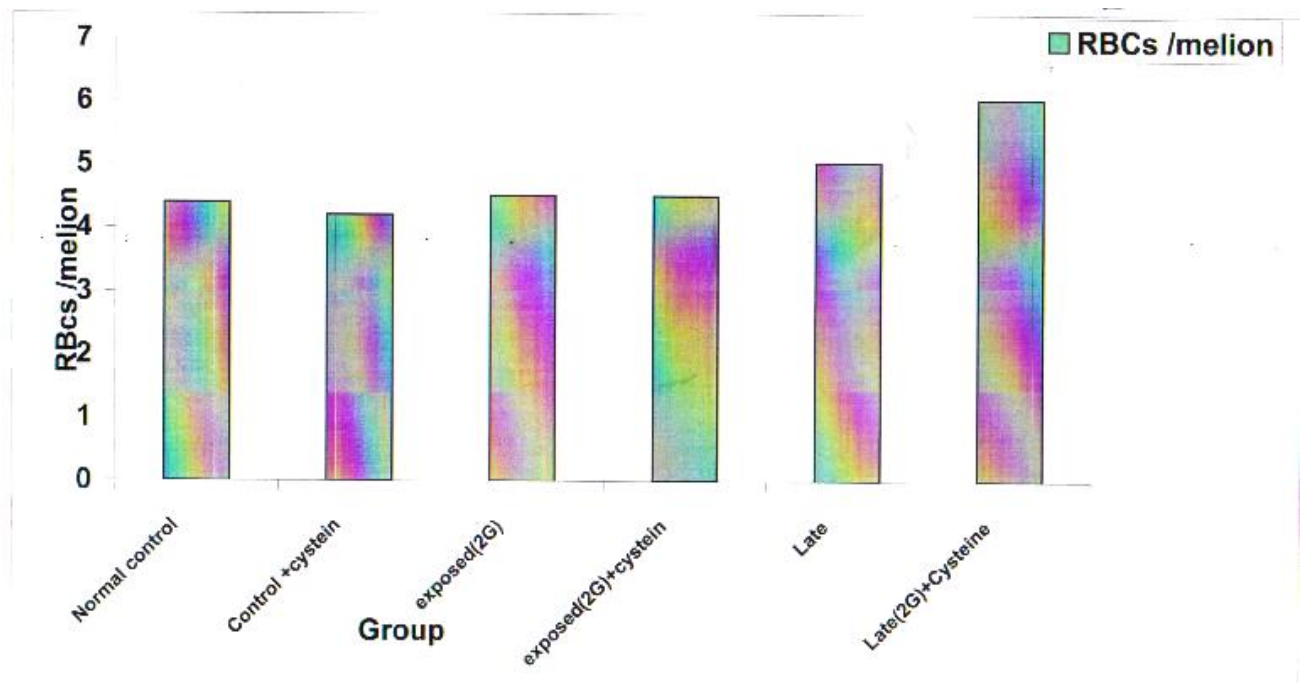

Fig 1:- Effect of EMF at (2 Gauss) on red blood cell count (RBCs /melion) for control groups and group exposed +Cystein

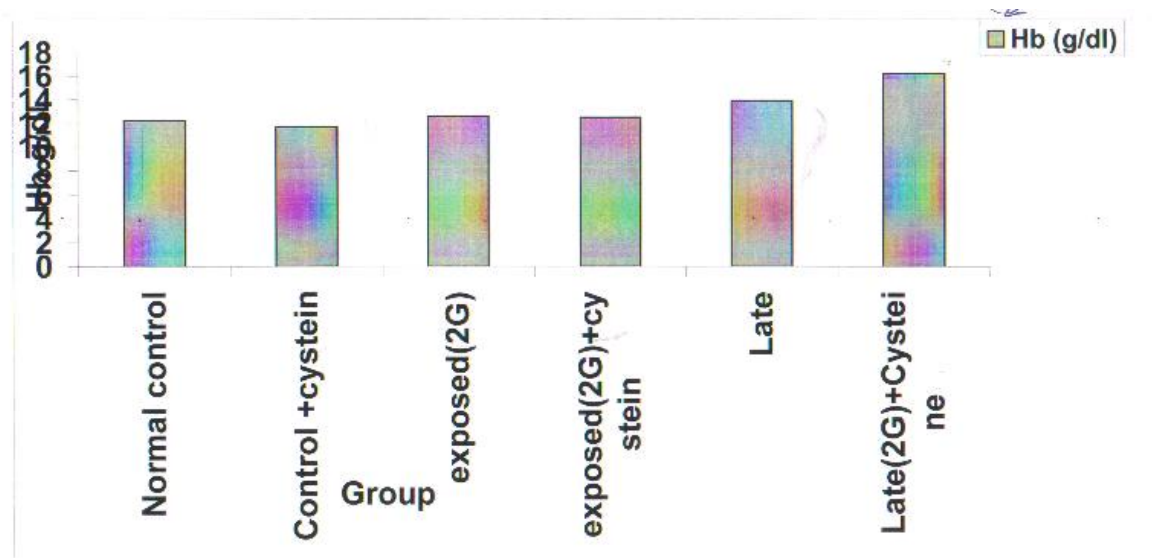

Fig 2:- $\quad$ Effect of EMF of (2 Gauss) of group exposed + cystein on hemoglobin concentration $(\mathrm{Hb} \mathrm{g} / \mathrm{dl})$. 


\section{Mervat Abdel-Rahman}

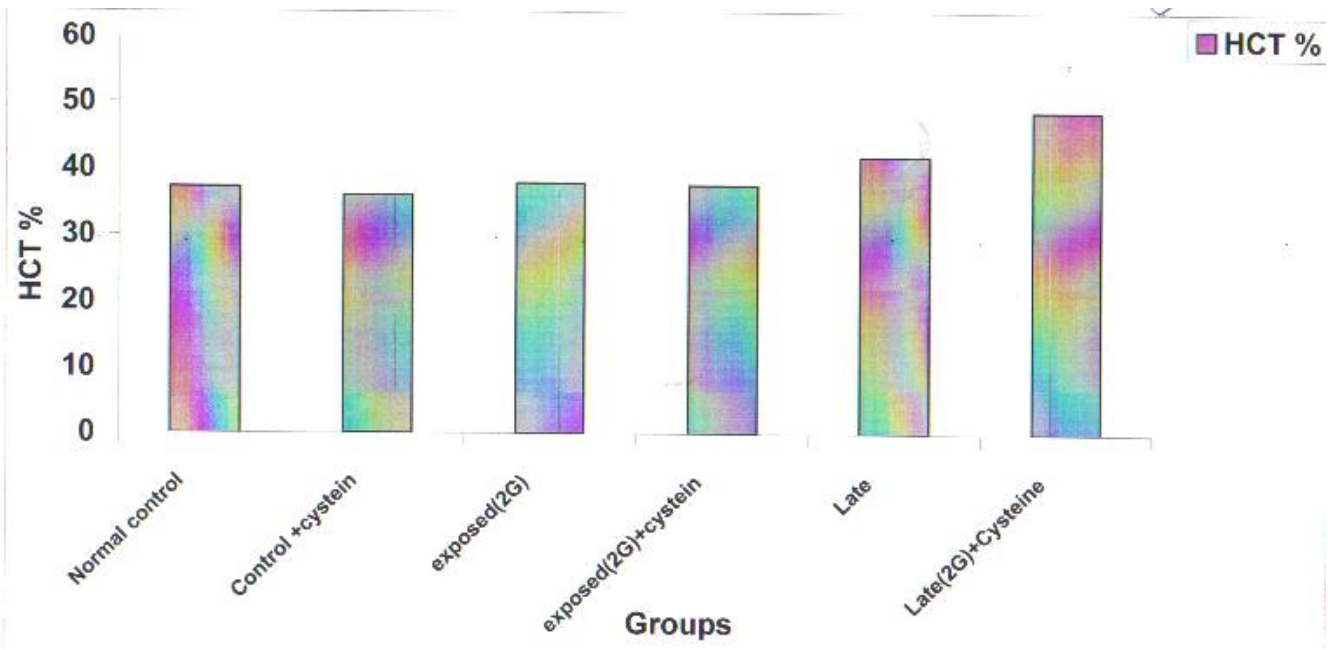

Fig 3:- Effect of EMF of (2 Gauss) on hematocait value (HCT \%) for control groups and group exposed + cystein

Fig 4:-

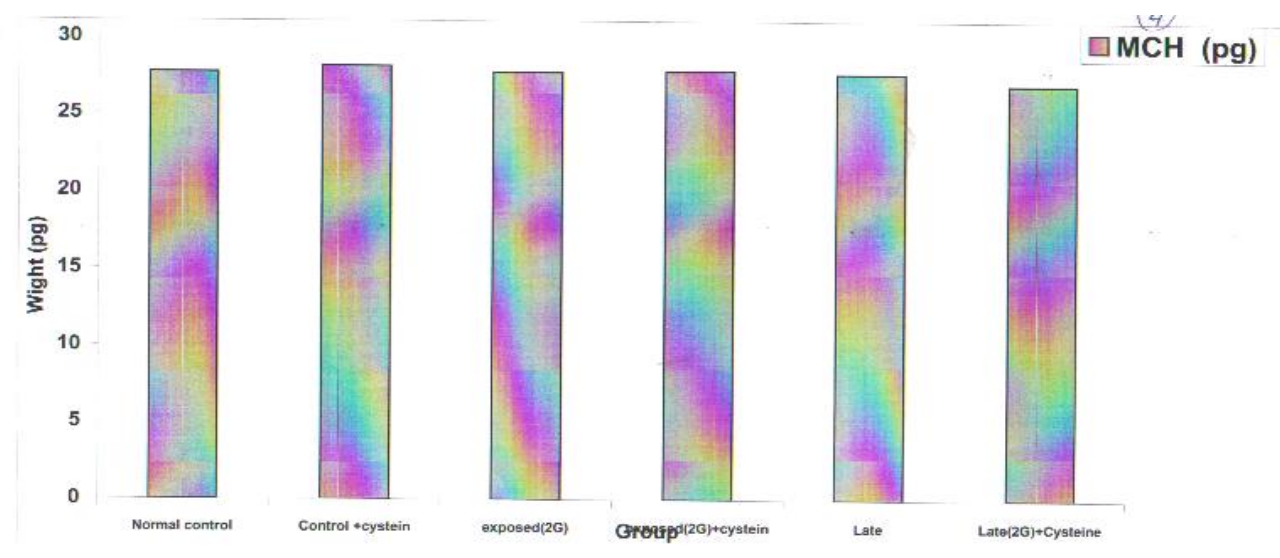

Effect of EMF of (2 Gauss) on mean corpuscular hemoglobin ( $\mathrm{MCH}$ pg) fof control group and group exposed +Cystein 


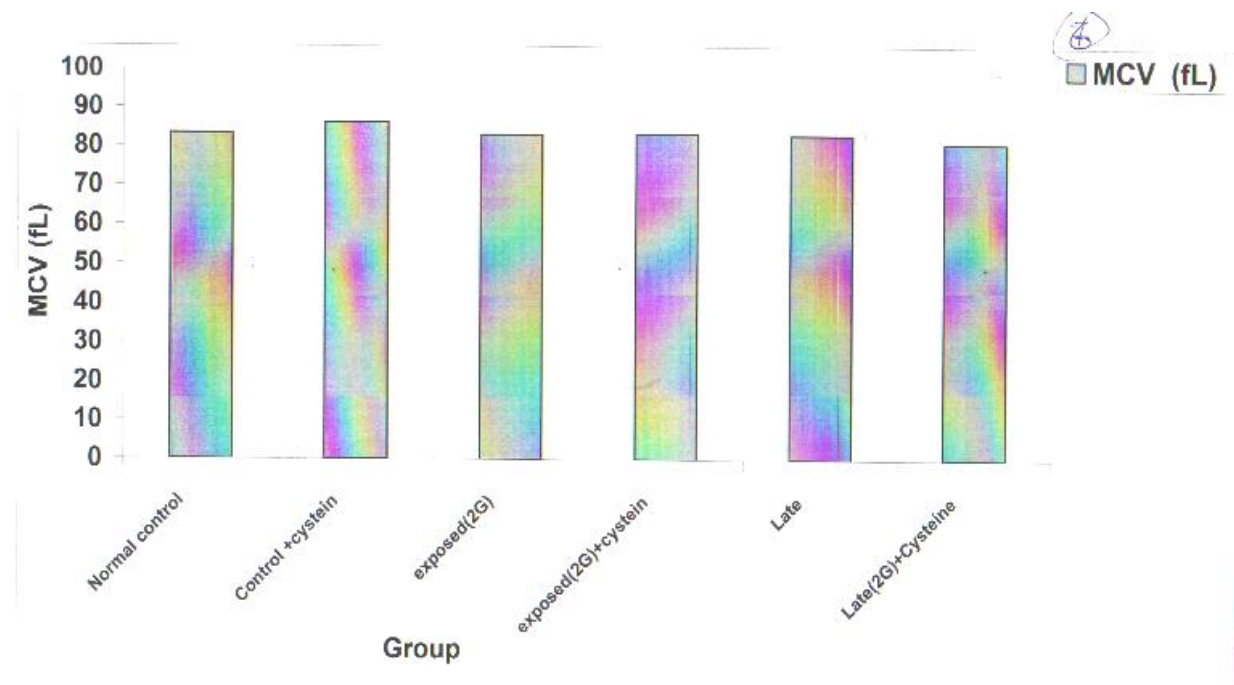

Fig 5:- $\quad$ Effect of EMF of (2Gauss) on mean corpuscular volume (MCV fL) for control group and group exposed + Cystein

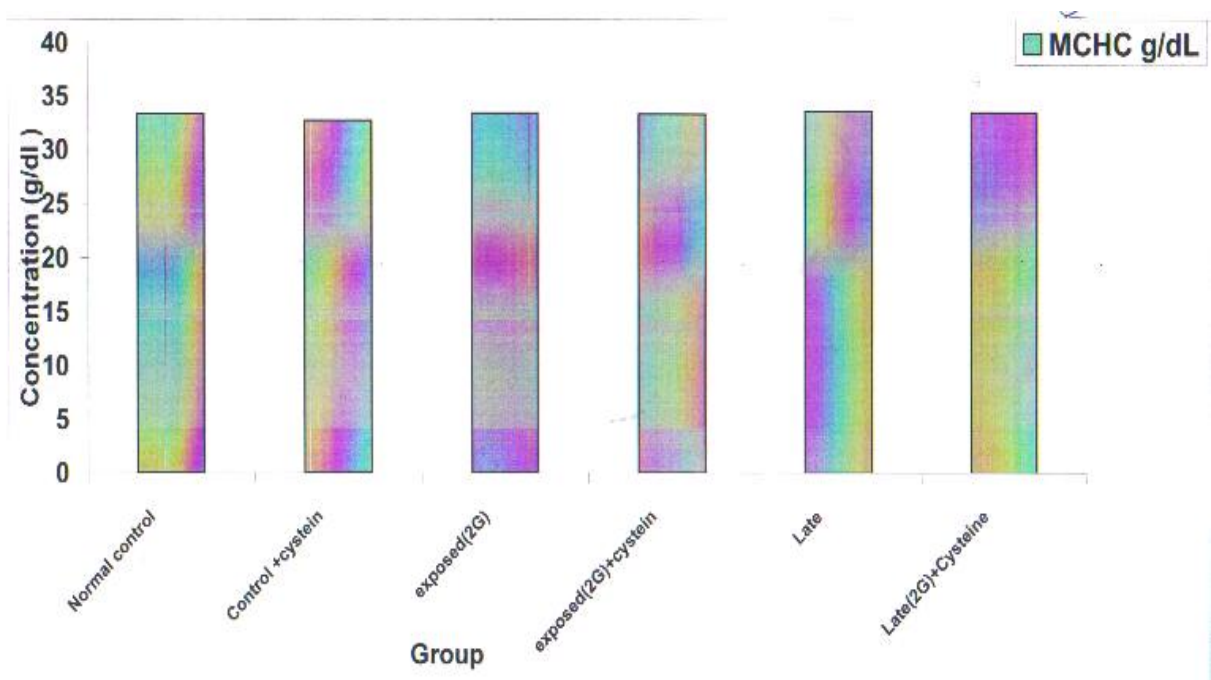

Fig 6:- $\quad$ Effect of EMF of (2 Gauss) on mean corpuscular hemoglobin 


\section{Mervat Abdel-Rahman}

\section{Discussion}

The present study provide evidence that exposure to 2 gauss EMF can result in some form of liver injury. This is because significant elevations of the hepatocellular enzymes AST and ALT were observed in plasma of rats at 21 days of exposure to EMF. These enzymes contained within the hepatocytes are released into blood after hepatocyte injury and increased cell membrane permeability. Serum bilirubin, a marker of liver damage and/or cholestatsis was also increased. Plasma glucose was significantly decreased by exposure to EMF, suggesting derangement of normal glucose homeostasis, which could be also of liver origin. The changes mentioned above were not observed in plasma of rat after the recovering period. This important observation, suggest that the biochemical changes observed can be reversed after avoiding exposure to the field.

Various reports suggest that the interaction site for ELF-EMF is the plasma membrane, since exposure determines altered $\mathrm{Ca}^{+2}$ influx (Flipo et al., 1998; Fanelli et al., 1999), as well as the clustering of integral plasma membrane proteins (Bersani et al., 1997). In addition, ELF-EMF-induced oscillations of intracellular $\mathrm{Ca}^{+2}$ concentration (Loschinger et al., 1998) have been correlated with changes in DNA, RNA and protein synthesis activities (Liburdy, 1992). More recently, the application of ELFEMF has been involved in the reduction (Fanelli et al., 1999) or stimulation (Flipo et al., 1998) of somatic cell apoptosis.

One mechanism by which EMF can affect biological systems, may be through increasing the generation of oxygen derived free radicals and oxidaive stress. Free radicals are generated under normal conditions in mitochondria as a consequence of oxidative phosphorylation in the respiratory chain. Additionally, they may be produced in response to many different endogenous and exogenous stimuli in the endoplasmatic reticulum, the peroxisomes, and the cytosol. Under certain conditions, reactive oxygen species may induce oxidative cell injury. Oxygen radical species such as superoxide radical, hydrogen peroxide and hydroxyl radical are highly reactive resulting in oxidative damage to lipids, proteins, and DNA (Haddad 2001; Papp et al., 2003).

The protection is provided by the antioxidant defense system, including enzymatic and non-enzymatic components. Thiol compounds, such as glutathione (GSH), cysteine $(\mathrm{CSH})$ and homocysteine $(\mathrm{HCSH})$ are a natural reservoir of the reductive capacity of the cell. The tripeptide L- $\gamma$ glutamyl-L-cysteinyl-glycine, or glutathione $(\mathrm{GSH})$, plays a major role in maintaining intracellular reduction-oxidation (redox) equilibrium in the lung. The cysteinyl moiety of GSH provides the reactive thiol as a functional element responsible for the diverse properties of glutathione (Haddad, 2001). $\mathrm{N}$ acetyl-L-cysteine (NAC), an antioxidant and a GSH precursor, has been shown to ameliorate cytokine transcription and synthesis, in addition to suppressing ROSmediated lung injury. In contrast, irreversible inhibition of $\gamma$-glutamylcysteine synthetase $(\gamma$ - GCS), the rate-limiting enzyme in GSH biosynthesis, by the action of L-buthionine$(S, R)$-sulfoximine (BSO), has been shown to enhance cytokine release by inducing the intracellular accumulation of ROS (Behrend et al., 2003). NAC ( $\mathrm{N}$-acetyl cysteine) is frequently used as a mucolitic and as an antidote in paracetamol intoxication ((Kucukardali et al., 2002; Zhao et al., 1998). NAC may maintain cell integrity by increasing the amount of glutathione within the cell or coming into direct reaction with spontaneous conjugation and/or reduction (Flanagan and Meredith , 1991).

In conclusion, the results obtained from the present observations indicated that animals treated with the anti-oxidant Lcysteine during the period of EMF exposure did not suffer from liver cell injury. This is in contrast to rats not treated with L-cysteine. 
This indicates that oxidative stress has been involved in the changes observed with liver enzymes and bilirubin. Whereas treatment after removal from the field of exposure did not significantly affect the studied parameters, except serum activity of GPT. This result is of particular interest since Lcysteine does not appear to be beneficial in preventing injury in this case. The results of the present work also indicated that removal from the field of exposure markedly lessened the changes seen in bilirubin, hepatocellular enzymes and blood glucose. This suggest that stopping exposure to EMF, e.g., by changing the job circumstances is necessary for those individuals whose work conditions subject them to long periods of exposure to EMF.

\section{Acknowledgement}

The author acknowledge the Biophysics Department at Bini Suif University for the facilities provided.

\section{References}

1. Bauer JD (1982). Clinical Laboratory Methods, $9^{\text {th }}$ ed. ST.Louis, Toronto, London: The C.V. Mosby Company.

2. Behrend L, Henderson G, Zwacka R.M (2003). Reactive oxygen species in oncogenic Transformation Molecular Mechanisms of Signalling. Biochemical Society Transactions $31 ; 1441-44$

3. Bersani, F., Marinelli, F., Ognibene, A. et al. (1997). Intramembrane protein distribu-tion in cell cultures is affected by $50 \mathrm{~Hz}$ pulsed magnetic fields. Bioelectromagnetics, 18, 463-469.

4. Barrett EG, Johnston C, Oberd)rster G, Finkelstein JN (1999). Antioxidant treatm-ent attenuates cytokine and chemokine levels in murine macrophages following silica expo-sure. Toxicol Appl Pharmacol 158: 211-220.

5. Chater S, Abdelmelek H , Sakly M \& Rhouma K (2004). Effects of sub-acute exposure to magnetic field on synthesis of plasma corticosterone and liver metallothionein levels in female rats. Pak J Med Sci 20 (3) 219-223.

6. Choi J, Liu RM, Kundu RK, Sangiorgi $F$, Wu W, Maxson $R$, Forman HJ. (2000) Molecular mechanism of decreased glutathione content in human immunodeficiency virus type 1 Tattransgenic mice. J Biol Chem.; 275 : 3693-8.

7. Crowley LV (1967). The ReitmanFrankel colorimetric transaminase procedure in suspected myocardial infarction. Clin Chem 13: 482-7.

8. Cuzzocrea, S., Mazzon, E., Costantino, G., Serraino, I., Dugo, L., Calabr, G., Cucinotta, G., De Sarro, A., Caputi, A. P. (2000). Beneficial effects of $\mathrm{n}$-acetylcysteine on ischaemic brain injury. $\mathrm{Br} . \mathrm{J}$. Pharmacol. 130: 1219-1226.

9. Fanelli, C., Coppola, S., Barone, R. et al. (1999). Magnetic fields increase cell survival by inhibiting apoptosis via modulation of $\mathrm{Ca}^{+2}$ influx. FASEB J., 13, 95-102.

10.Flanagan RJ and Meredith TJ (1991). Use of $\mathrm{N}$-acetylcysteine in clinical toxicology. Am J Med 91 (Suppl 3C): 131-139

11.Flipo, D., Fournier, M., Benquet, C. et al. (1998): Increased apoptosis, changes in intracellular $\mathrm{Ca}^{+2}$ and functional alterations in lymphocytes and macrophages after in vitro exposure to static magnetic field. $J$. Toxicol. Environ. Health, 54, 63-76.

12. Fiorani M, Biagiarelli B, Vetrano F, Guidi G, Dacha M, Stocchi V (1997). In vitro effects of $50 \mathrm{~Hz}$ magnetic fields on oxidat-ively damaged rabbit red blood cells, Bioelectromagnetics 18 ;125-131.

13.Haddad JJ (2001). Reductionoxidation signalling mediating MAPKp38-dependent regulation of pro-inflammatory cytokine biosynthesis: On the mechanism of glutath-ione as a novel immunoregulatory antioxi-dant thiol. Int Arch Biosci 34:1001-1013

14. Haddad JJ, Safieh-Garabedian B, Saadé NE, Kanaan SA, Land SC 


\section{Mervat Abdel-Rahman}

(2001). Chemioxyexcitation $(\Delta p \mathrm{O} 2 / \mathrm{ROS})$-depende-nt release of IL-1 $\square$, IL-6 and TNF-J: Evidence of cytokines as oxygen sensitive mediators in the alveolar epithelium. Cytokine 13: 138-147.

15.Hadi Yasa M, Kacmaz M, Serda Ozturk M, Durak J. (1999) Antioxidant status of erythrocyte from patients with cirrhosis. HepatoGastroenterology.; 46: 2460-3.

16. Kabuto H., Yokoi I., Ogawa N., Mori A., Liburdy, R.P. (2001). Effects of magnetic fields on the accumulation of thiobarbituric acid reactive substances induced by iron salt and $\mathrm{H} 2 \mathrm{O} 2$ in mouse brain homogenates phosphotidylcholine, Pathophysiology 7; 283-288.

17. Kucukardali Y, Cinan U, Acar HV, Ozkan S, Top C, Nalbant S, Cermik H, Cankir Z, Danaci M (2002). Comparison of the therapeutic efficacy of 4methylpyrazole and $\mathrm{N}$-acetylcysteine on acetaminophen (paracet-amol) hepatotoxicity in rats. Curr Med Res Opin 18: 78-81

18. Lee BC, Johng HM, Lim JK, Jeong JH, Baik KY, Nam TJ, Lee JH, Kim J, Sohn UD (2004). Effects of extremely low frequency magnetic field on the antioxidant defense system in mouse brain: a chemiluminescence study. Journal of Photochemistry and Photobiology B: Biology 73; 43-48

19.Liburdy, R.P. (1992) Calcium signaling in lymphocytes and ELF fields. Evidence for an electric field metric and a site of interaction involving the calcium ion channel. FEBS Lett., 301, 53-59.

20. Loerther, H.J. and Mc Tavish, D.G. (1976) Descreptive and inferential statiscs an introduction. Bostan, allyn and bacan.

21.Loschinger, M., Thumm, S., Hammerle, H. et al. (1998) Stimulation of protein kinase A activity and induced terminal differentiation of human skin fibroblasts in culture by low- frequency electromagnetic fields. Toxicol. Lett., 96-97, 369-376.

22.Lalo U.V., Pankratov Y.V., Mikhailik, O.M (1994). Steady magnetic fields effect on lipid peroxidation kinetis, Redox Rep. 1; 71-75.

23. Loomis DP, Savitz DA, Ananth CV (1994). Breast cancer mortality among female electrical workers in the United States. J Nat Cancer Inst 86: 921-25.

24.Pasquinelli, P.; Petrini, M.; Mattii, L.; Galimberts, S.; Saviozz, M.; Malvaldi, G (1993). Biological effects of PEMF (Pulsing electromagnetic field): An attempt to modify cell resistance to, anticancer agents. J. Environ. Path. Toxical. Oncal 12 (4), 193-197

25.Papp E, Nardai G, Soti $\mathbf{C}$ and Csermely $P$ (2003). Molecular chaperones, stress proteins and redox homeostasis. BioFactors 17;249-257

26.Petrini, M; Mattii, L.; Sabbatini, A.; Carulli, G.; Grassi, B.; Cadossi, R.; Ronea, G.; Conte, A (1990). Multidrug resistance and electromagnetic fields. J. Bioelectr. 9, 209-212.

27. Reimund J-M, Allison AC, Muller CD, Dumont S, Kenney JS, Baumann R, Duclos B, Poindron P (1998). Antioxidants inhibit the in vitro production of inflammatory cytokines in Crohn's disease and ulcerative colitis. Eur J Clin Invest 28: 145-150.

28. Roy S, Noda Y, Eckart V, Traber MG, Mori A, Liburdy R, Packer L (1995). The phorbol 12-myristate 13-acetate (PMA)-induced oxidative burst in rat peritoneal neutrophils is increased by a $0.1 \mathrm{mT}(60 \mathrm{~Hz})$ magnetic field. FEBS Lett. 376; 164166.

29.Savitz, D.A., Wachtel, H., Barnes, F.A., John, E.M., and Tvrdik, J.G. (1988). Case-control study of childhood cancer and exposure to 60 $\mathrm{Hz}$ magnetic fields. Am. J. Epidemiol. 128: 21-38.

30. Wrensch M, Bondy ML, Weinche 


\section{Effect Of L-Cysteine On Blood Picture And........}

J, Yost M (1993). Environmental risk factors for primary malignant Brain tumors: A review, J Neurooncol 17: 47-64.

31.Zhao C, Sheryl D, Zhou YX (1998):

Effects of combined use of diallyl disulfide and Nacetyl-cysteine on acetaminophen hepatoto-xicity in $\square$ naphthoflavone-pretreated mice. World J Gastroenterol 1998; 4: 112116 


\title{
Mervat Abdel-Rahman
}

\section{تأثير السيستين علي صورة الام وعلي دلالات مختلفة بالام في الفئران التي تم تم

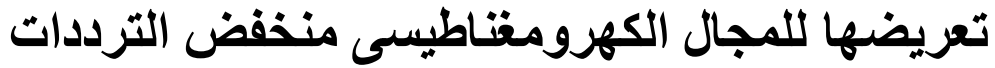

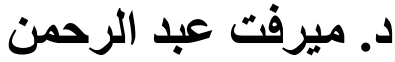 \\ معمل الباتولوجيا الاكلينيكية، مستشفي الطلبة، جامعة القاهرة. الجيزة
}

هدف هذا البحث دراسة تأثثير التعرض للمجال الكهرومغناطيسى منخفض الترددات على التى

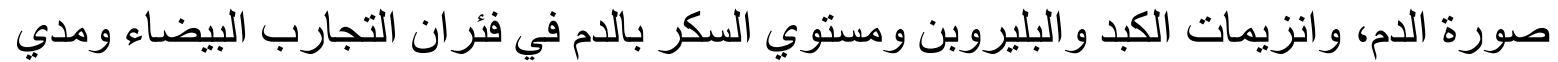

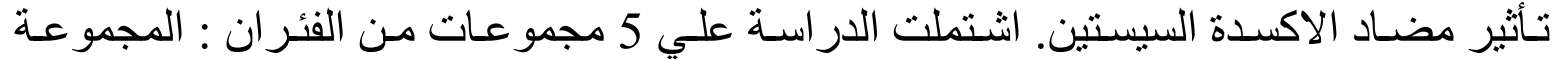

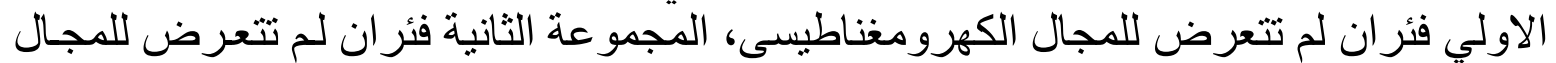

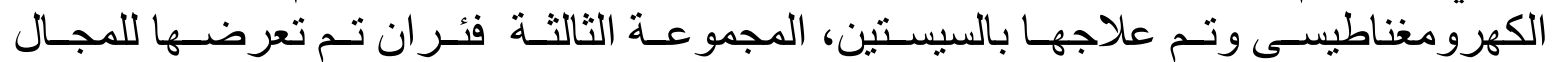

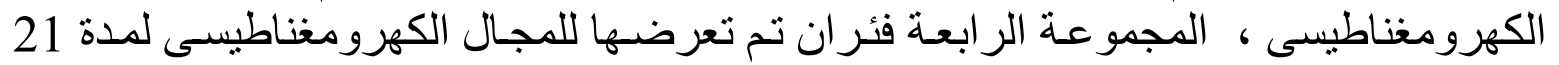

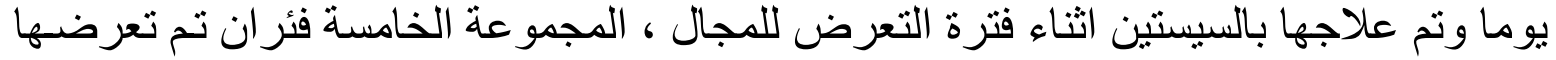

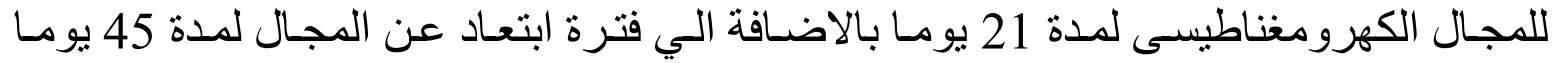

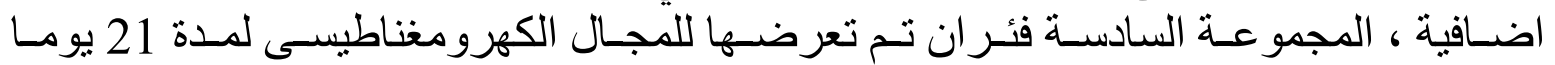

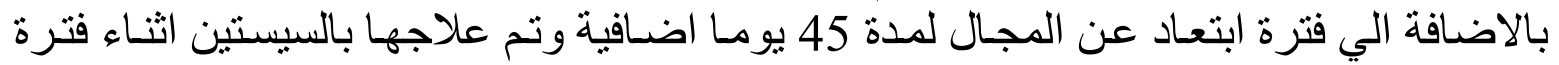
التعرض للمجال وكذلك اثناء فترة النقاهة من المجاد المجال.

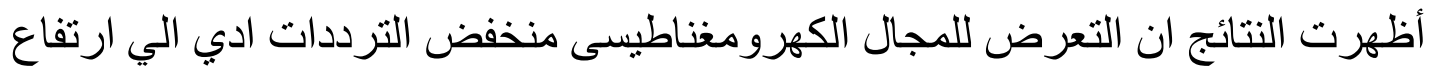

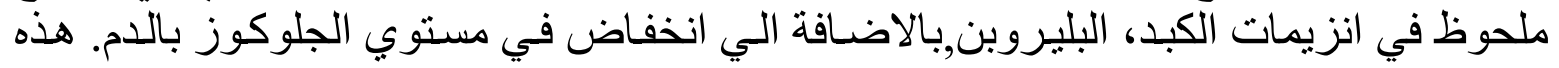

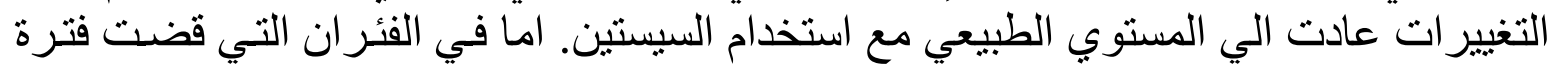

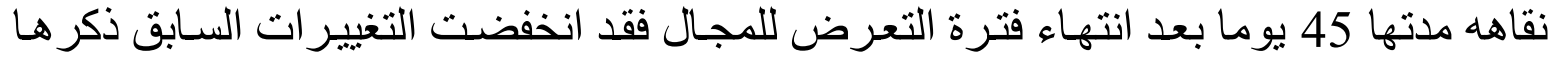

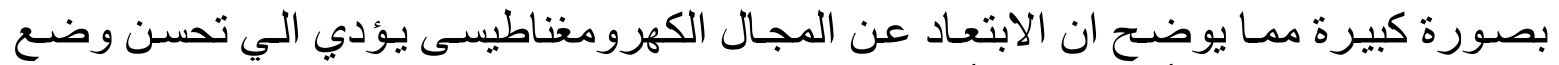

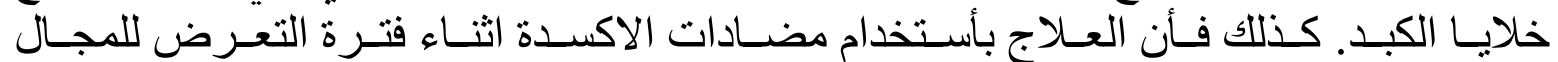
الكهرومغناطيسى له فائدة علاجية. 